\title{
Mendesain Ulang Kemasan dan Label Produk Kopi Odah
}

\author{
${ }^{1 *}$ Erma Sulistyo Rini, ${ }^{2}$ Ni Wayan Sri Arini, ${ }^{3}$ I Gst. A. Vony Purnama \\ D3 Manajemen Informatika ${ }^{1}$, S1 Sistem Komputer ${ }^{2}$, S1 Sistem Komputer ${ }^{3}$ \\ *Email: erma@stikom-bali.ac.id
}

\begin{abstract}
ABSTRAK
Desa Bakas Banjarangkan Klungkung adalah desa tua bernama "Bhala Akas", selain kondisi alam yang bagus, dari desa ini juga terdapat produsen kopi terkenal yaitu "Kopi Odah" milik keluarga Ibu Nyoman Resa sejak tahun 1969. Produsen kopi ini masih sangat produktif, rata-rata produksi $100 \mathrm{~kg}$ kopi bubuk perminggu atau setara $14-15 \mathrm{~kg}$ perhari. Pemasaran dan penjualan kopi tersebar di pasar tradisional desa kecamatan Klungkung, pasar dusun Banjarangkan dan Pasar Katrangan di Denpasar. Kopi ini memiliki cita rasa tersendiri dan istimewa dengan aroma yang khas, melalui proses produksi masih sangat tradisional dengan peralatan sederhana. Proses produksi dimulai dari pemanggangan atau roasting menggunakan alat rolling dan dibakar menggunakan kayu bakar, serta pengeringannya dilakukan di bawah sinar matahari, selanjutnya biji kopi digiling menjadi bubuk kopi dan dibungkus menggunakan plastik kiloan sebagai kemasan untuk dijual ke pasar tradisional di desa. Pendampingan mendesain ulang kemasan kopi dan memberikan label kemasan dilaksanakan oleh tim kegiatan pengabdian masyarakat STIKOM Bali. Kegiatan dimulai dengan perkenalan, sosialisasi, evaluasi dan pelaporan, hasil dari kegiatan adalah kemasan produk lebih menarik dengan label Kopi Odah dengan perluasan pemasaran secara online.
\end{abstract}

Kata kunci : produk, desain ulang, kemasan dan label

\section{ABSTRACT}

The village of Bakas Banjarangkang Klungkung, the old village called "Bhala Akas", with good nature and a famous coffee producer with "Kopi Odah". This business is owned by Mrs. Nyoman Resa's family since 1969. Coffee producers are still very productive, producing an average of $100 \mathrm{~kg}$ coffee in one week or 14-15 kg per day, coffee marketing and sales are spread in the traditional markets of the villages of Klungkung, Banjarangkan and Katrangan Markets in Denpasar. The coffe product has a taste and special aroma. The process of production is still traditional with simple equipment, begins with roasting process using a rolling tool and burned using firewood, and drying is done in the sun, and ground into coffee powder and wrapped using simple plastic pouch as packaging to be sold to traditional markets in the village. STIKOM Bali social service activity is carried out in assisting in redesigning coffee packaging and providing label furniture. The activity comprises 
introduction, socialization, evaluation and reporting, the result of the activity was more attractive product packaging with Kopi Odah Label with the expansion of online marketing.

Key words: product, redesign, packaging and label

\section{PENDAHULUAN}

Kabupaten Klungkung merupakan Kabupaten yang paling kecil dengan 4 (empat) kecamatan yaitu 1) Kecamatan terkecil klungkung dengan luas $2.095 \mathrm{Ha}$, 2) Kecamatan Dawan dengan luas 37,38 $\mathrm{Km}^{2}$. 3) Kecamatan Nusa Penida terdiri dari tiga kepulauan yaitu pulau Nusa Penida, Pulau Lembongan dan Pulau Ceningan, yang terdiri dari 16 Desa Dinas, dan 4) Kecamatan Banjarangkan dengan luas wilayah 45,73 $\mathrm{km}^{2}$. Secara administratif kecamatan Banjarangkan, terdiri dari 13 desa, 55 dusun, dan 29 desa adat didukung dengan beberapa sarana seperti 10 pasar umum, 7 koperasi yang sudah berbadan hukum, 3 buah KUD dan 3 buah Bank serta 26 buah LPD yang dapat dimanfaatkan oleh masyarakat untuk memajukan perekonomian Desa (K.Budiarta, 2020) Masing - masing kecamatan memiliki potensi yang mampu meningkatkan perekonomian mikro melalui pemberdayaan potensi wilayahnya. Selain kerajinan potensi lain yang menjadi fokus pemerintah daerah Kabupaten Klungkung adalah desa wisata. Salah satu desa di kecamatan ini ditetapkan sebagai desa wisata oleh Pemerintah Kabupaten Klungkung. Desa tersebut adalah Desa Bakas dengan wisata tracking dan spot selfie instagramable. Jarak dari kecamatan ke Desa Bakas kurang lebih $3 \mathrm{~km}$, sebelah Utara Desa berbatasan dengan Desa Nyalian, sebelah Timur Desa Getakan, sebelah Selatan Desa Tusan, dan sebelah Barat Desa Guliang. Suasana pedesaan masih sangat terasa kental, dengan hamparan sawah yang sangat luas dan germicik air mengalir pada irigasi masih cukup jernih sedangkan di seberang lembah sebelah timur tepatnya di Desa Getakan terlihat sawah berbentuk teras sering. Potensi alam seperti inilah yang menjadikan daya tarik sendiri Desa Bakas, sebagai Desa tua yang dibangun sejak lama, bersama-sama sekelompok masyarakat yang dulunya diberi nama "Bhala Akas" yang berarti wahyu atau sabda dari Sang Hyang Tohlangkir atau Mahadewa yang bersemayam di Gunung Agung, Desa Bakas, Banjar Kawan Kecamatan Banjarangkan Kabupaten Klungkung Semarapura Provinsi Bali, memiliki luas Desa 2,82 $\mathrm{Km} 2$ dengan jumlah jiwa 2.491 jiwa di tahun 2015 (Badan Pusat Statistik, Klungkung, 2020).

Selain sebagai desa wisata, di Desa Bakas, Banjar Kawan memiliki warga yang masih sangat produktif sebagai produsen kopi Bali. Kopi merupakan minuman ke-2 terpopuler di dunia setelah teh, bagi banyak orang kopi bukan lagi sekedar minuman selingan saja, tetapi sudah menjadi bagian dari gaya hidup masyarakat. Indonesia merupakan salah satu produsen kopi terbesar di dunia oleh karena itu Indonesia ditetapkan sebagai negara keempat penghasil kopi terbesar di dunia, dengan kekayaan ragam dan jenis kopinya yang tersebar di berbagai daerah di Indonesia mulai dari Sumatra, Jawa, Bali, Sulawesi, Nusa Tenggara hingga Papua. Sebutan populer kopi di Indonesia juga beragam di antaranya ada kopi Gayo yang terkenal dari Aceh, Sidikalang dari Jawa, Kopi Kintamani dari Bali, Kopi 
Flores dari Nusa Tenggara, Kopi Wamena dari Papua serta banyak lagi sebutan lain. Sebagai salah satu produsen kopi populer di Indonesia, Klungkung merupakan salah satu daerah yang memiliki produsen kopi Bali yang cukup terkenal, khususnya di Banjar Kawan Desa Bakas Kecamatan Banjarangkan. Kopi tersebut dikenal dengan kopi bali "Bhala Akas", milik Ibu Nyoman Resa. Industri rumah tangga (IRT) ini sudah berjalan cukup lama, berdasarkan hasil observasi awal pada Ibu Nyoman Resa, dan selanjutnya disebut sebagai mitra dalam kegiatan pengambdian masyarakat (PM) ini.

Mitra merupakan produsen kopi Desa Bakas yang masih produktif dan cukup terkenal, dengan rata-rata penjualan $100 \mathrm{~kg}$ kopi bubuk perminggu atau setara $14-15 \mathrm{~kg}$ perhari yang tersebar di pasar tradisional desa di Kecamatan Klungkung, pasar Dusun Banjarangkan dan Pasar Katrangan di Denpasar. Menurut konsumen, kopi produksi mitra memiliki rasa yang istimewa, karena diproses masih dengan cara tradisonal mulai dari proses pemanggangan menggunakan alat rolling dan dibakar menggunakan kayu bakar, serta pengeringannya dilakukan di bawah sinar matahari, selanjutnya digiling menjadi bubuk kopi dan dibungkus menggunakan plastik kiloan sebagai kemasan belum kedap udara untuk dijual ke pasar tradisional di Desa. Pengemasan yang masih sangat sederhana ini sangat rentan terhadap kerusakan dan kebocoran pada saat pengiriman, terbatas masa simpan serta tidak menarik. Pengemasan sederhana tersebut dianggap belum layak apabila penjualan kopi hendak dikembangkan melalui pasar modern atau pasar digital di masa mendatang. Untuk membantu permasalah mitra, kegiatan pengabdian masyarakat difokuskan pada sisi pengemasan dan labeling mengingat jumlah produksi rata-rata per hari atau perminggunya cukup besar dan hampir $80 \%$ kopi yang dijual di pasar tradisional desa dan kabupaten adalah kopi berasal dari mitra. Hal ini menandakan bahwa mitra memiliki peluang besar untuk dikembangkan.

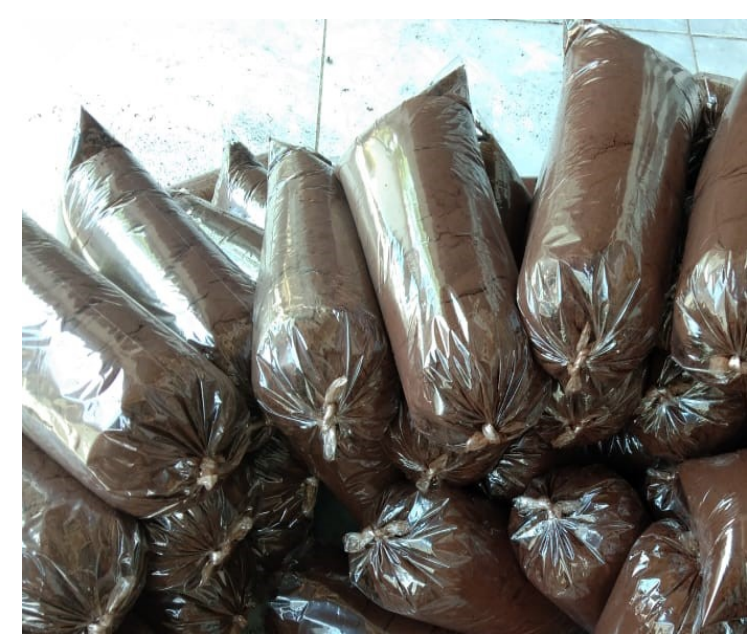

Gambar 1 Kemasan produk Kopi Odah sebelum kegiatan PKM dilaksanakan

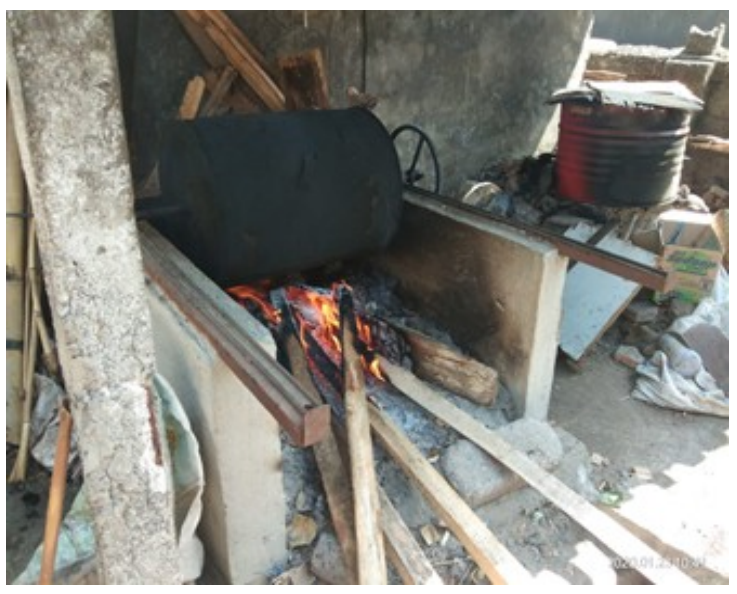

Gambar 2 Proses roasting atau pemangangan kopi 


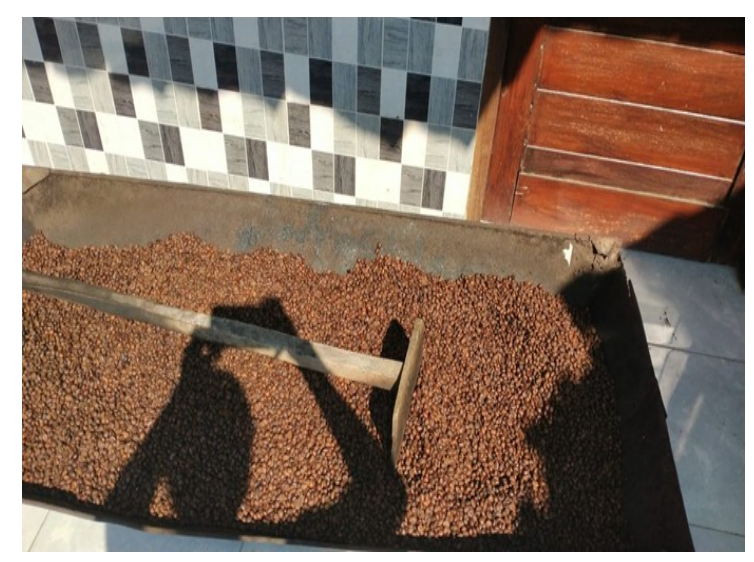

Gambar 3 Proses penjemuran kopi setelah proses roasting

\section{RUMUSAN MASALAH}

Rumusan masalah mitra berdasarkan hasil analisis situasi mitra sesuai dengan pemaparan dapat dijelaskan sebagai berikut:

1. Pengemasan masih menggunakan plastik kiloan bening dan tidak kedap udara hal ini sangat beresiko terjadi kebocoran dan kerusakan di samping itu bisa memperpendek masa simpan karena kemasan tidak kedap udara.

2. Pengemasan yang masih sangat sederhana pada gambar 1 dan tanpa identitas atau label tidak menarik dan tidak layak untuk pengembangan pemasaran ke pasar modern dan pasar digital.

3. Produk kopi mitra cukup terkenal dengan nama "Kopi Odah" tetapi nama ini belum pernah dibuatkan label resmi di kemasan kopi tetapi hanya pengenalan dari pengecer dan pelanggan saja.

\section{METODE}

1. Prosedur Kegiatan

Prosedur kegiatan digambarkan dalam tahapan berikut :

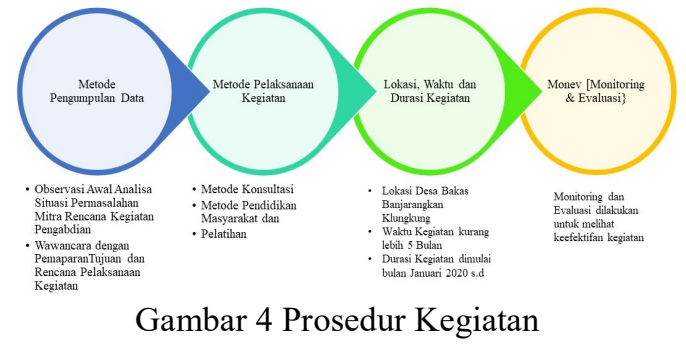

2. Metode Pengumpulan Data

1) Observasi awal dilakukan untuk menganalisa situasi dan mengetahui lebih detail tentang permasalahan mitra sebagai upaya untuk menyusun rencana jadwal kegiatan pengabdian.

2) Wawancara dilakukan dengan memaparkan tentang tujuan dan rencana pelaksanaan kegiatan serta timeline atau jadual kegiatan.

3. Metode Pelaksanaan Kegiatan

Metode yang digunakan untuk membantu penyelesaian permasalahan mitra adalah sebagai berikut :

1) Metode Konsultasi; melalui (a) sosialisasi awal ke mitra guna menjelaskan tentang tujuan kegiatan dilaksanakan, (b) diskusi terkait dengan permasalahan yang dialami mitra dan solusi yang bisa diberikan atau dibantu oleh Tim Pengabdian ITB STIKOM Bali (c) Menjelaskan jadual atau timeline kegiatan dan tim pakar dari ITB STIKOM Bali sebagai pendamping kegiatan.

2) Pendidikan Masyarakat meng gunakan model kegiatan penyuluhan yang bertujuan untuk meningkatkan pemahaman serta kesadaran mitra terhadap (a) fungsi dan manfaat pengemasan yang baik bisa membantu memperpanjang masa simpan juga dapat meningkatkan value atau nilai produk, (b) pentingnya penggunaan labeling atau 
logo pada produk selain sebagai identitas produk juga dapat digunakan sebagai pengingat bagi konsumen atau pelanggan saat akan membeli kembali produk mitra.

3) Metode Pelatihan dengan model penyuluhan disertai dengan membuat contoh desain label dan logo baik desain label kemasan bagian belakang maupun desain logo kemasan bagian depan menggunakan tools yang sudah disediakan online canva.com sampai dengan terealisasinya desain logo dan label produk yang siap dicetak serta digunakan pada produk mitra.

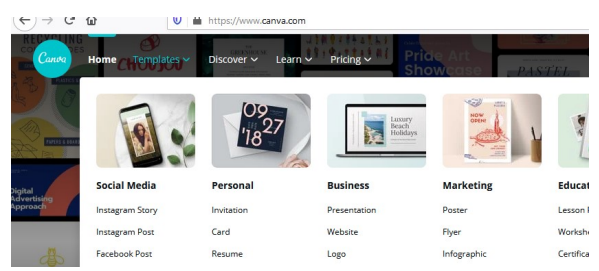

Gambar 5 Tools online Canva
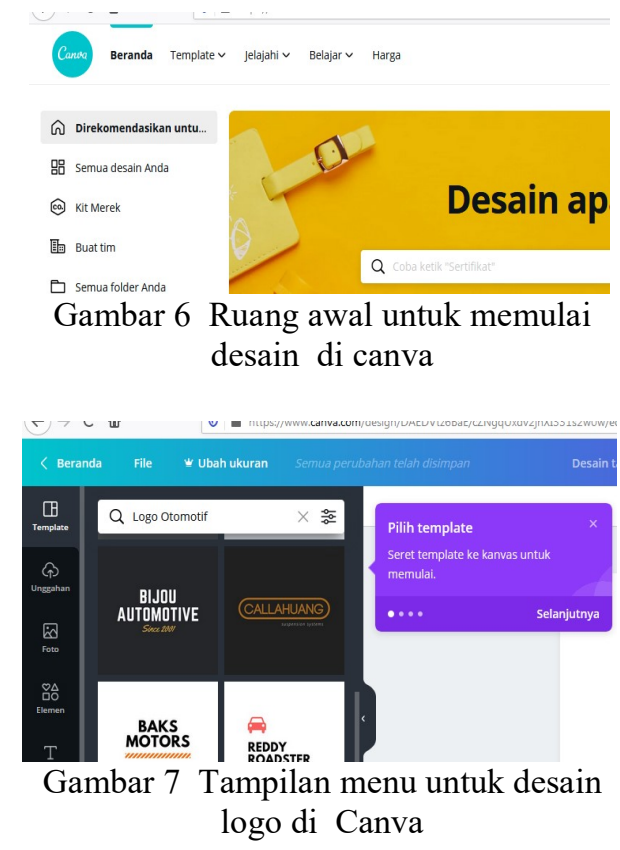

4. Lokasi, Waktu dan Durasi Kegiatan
Mitra merupakan produsen kopi dari Desa Bakas Kecamatan Banjarangkan Kabupaten Klungkung, lokasi mitra berjarak kurang lebih $32.5 \mathrm{~km}$ dari Kampus ITB STIKOM Bali dengan jarak tempuh kurang lebih 45 menit menggunakan kendaran roda empat (mobil).

Sesuai dengan perencanaan kegiatan dilaksanakan dalam jangka waktu 6 (enam) bulan dimulai pada bulan Januari sampai dengan bulan Juni 2020.

5. Monev (Monitoring dan Evaluasi )

Monitoring dan evaluasi kegiatan dilakukan guna mengetahui keefektifan serta keberhasilan kegiatan secara keseluruhan

\section{PEMBAHASAN}

Berikut gambaran proses pelaksanaan kegiatan dengan menggunakan 3 (tiga) metode meliputi konsultasi, pendidikan masyarakat serta pelatihan.

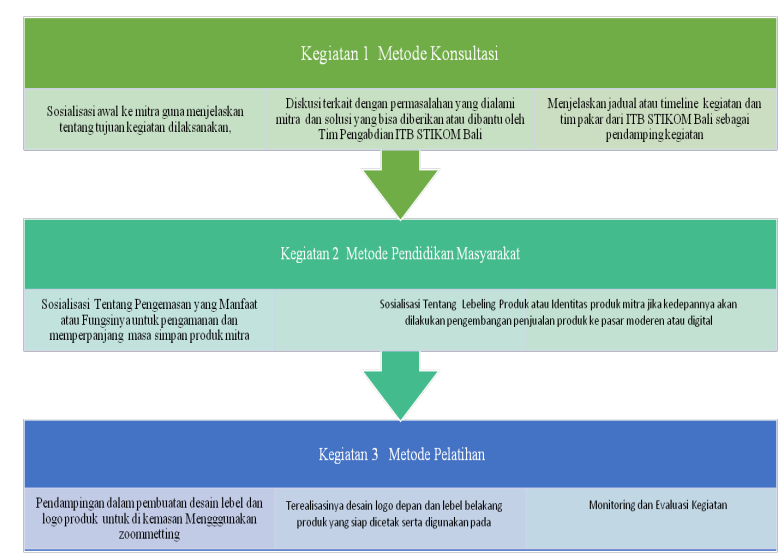

Gambar 8 Proses Pelaksanaan Kegiatan

Pada gambar di atas, digambarkan tentang proses pelaksanaan kegiatan pengabdian masyarakat (PKM), mulai dari tahap awal untuk :

Kegiatan 1, melakukan observasi awal dengan model sosialisasi untuk 
menganalisis situasi permasalahan mitra, pemaparan tentang tujuan dan rencana pelaksanaan kegiatan pengabdian, dilanjutkan dengan diskusi terkait dengan permasalahan yang dialami mitra dan solusi yang bisa diberikan atau dibantu oleh Tim Pengabdian ITB STIKOM Bali dan tim pakar dari ITB STIKOM Bali sebagai pendamping.

$\checkmark$ Kegiatan 2 melakukan sosialisasi tentang fungsi dan manfaat pengemasan yang baik guna memperpanjang masa simpan produk. Dilanjutkan dengan sosialisasi pentingnya penggunaan label atau logo pada produk selain sebagai identitas produk juga dapat digunakan sebagai pengingat bagi konsumen atau pelanggan saat akan membeli kembali produk mitra, disamping dapat meningkatkan value atau nilai produk. (C.Cenadi, 2019) Tujuan dari kegiatan ini untuk meningkatkan pemahaman, kesadaran serta pengetahuan mitra.

$\checkmark$ Kegiatan 3 melakukan pendampingan pembuatan desain label belakang kemasan produk mitra dan desain logo depan kemasan sebagai identitas produk sampai dengan disepakatinya desain label dan logo produk oleh mitra sehingga bisa direalisasikan untuk dilakukan pencetakan dengan model sticker untuk label belakang kemasan dan logo depan kemasan. Akhir dari kegiatan ini adalah dilakukannya monitoring dan evaluasi kegiatan guna mengukur efektifas dan efesiensi kegiatan .

Kepakaran tim yang terlibat pada usulan pengabdian masyarakat ini yang disesuaikan dengan kondisi mitra; terdiri atas bidang ilmu manajemen, teknologi informasi serta multimedia. Dukungan mitra diberikan dalam bentuk partisipasi mitra dalam menyediakan tempat yang digunakan selama kegiatan dilaksanakan serta berperan aktif dalam proses kegiatan seperti tanya jawab selama sosialisasi, penyuluhan dan pelatihan berlangsung

Berikut dipaparkan bukti kegiatan dan hasil kegiatan.

1. Pengukuran hasil kegiatan penyuluhan tentang manfaat dan fungsi pengemasan yang baik, mitra memahami pentingnya fungsi dan manfaat dari pengemasan yang baik serta peranan label produk sebagai identitas usaha, pengukuran pemahaman menggunakan kuisioner setelah dilengkapi dan diisi oleh mitra diperoleh ringkasan sebagai berikut.

Tabel 1 Hasil Pengukuran Keberhasilan Kegiatan Penyuluhan

\begin{tabular}{|l|c|c|}
\hline Indikator Pengukuran & $\begin{array}{c}\text { Rata2 Nilai } \\
\text { Kreteria }\end{array}$ & Prosentase \\
\hline Pelaksanaan kegiatan & 4 & $80 \%$ \\
\hline Pembicara & 4,6 & $93 \%$ \\
\hline Pemahaman Mitra & 3,75 & $75 \%$ \\
\hline
\end{tabular}

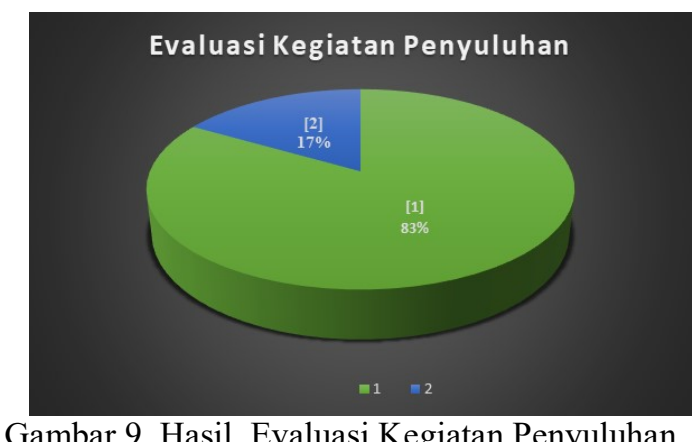

Gambar 9 Hasil Evaluasi Kegiatan Penyuluhan

2. Desain label kemasan belakang produk mitra dan desain logo kemasan depan 


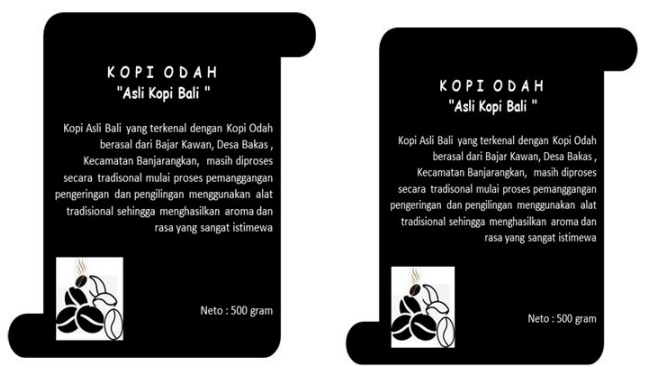

Gambar 10 Desain Label Kemasan Produk Bagian Belakang

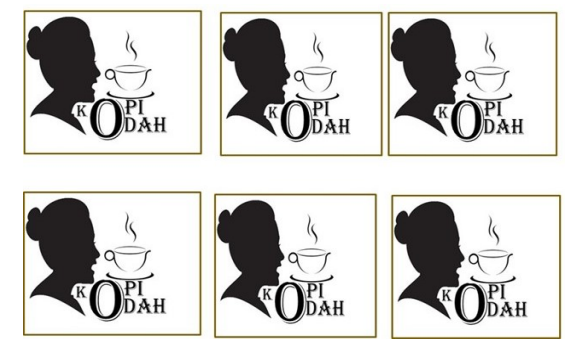

Gambar 11 Desain Logo Kemasan Produk Bagian Depan

3. Monitoring dan Evaluasi kegiatan bertujuan untuk mengetahui sampai sejauh mana program yang direncanakan mencapai target atau sasaran yang diinginkan serta melihat kendala dan permasalahan yang mungkin terjadi selama keberlangsungan program. Proses evaluasi kegiatan akan dilaksanakan dengan pengukuran keberhasilan kegiatan menggunakan form evaluasi penilaian pelaksanaan dan formulir evaluasi monitoring kegiatan sebagai mitra dan peserta.

Tabel 2 Hasil Pengukuran Monitoring dan Evaluasi Kegiatan

\begin{tabular}{|l|c|c|}
\hline \multicolumn{1}{|c|}{ Deskripsi Kegiatan } & Ketidakpuas an & Ke puas an \\
\hline $\begin{array}{l}\text { Evaluasi dan } \\
\text { Monitoring Kegiatan } \\
\text { Pengabdian }\end{array}$ & $18 \%$ & $82.33 \%$ \\
\hline
\end{tabular}

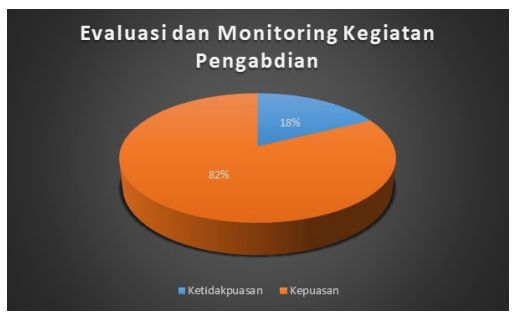

Gambar 12 Hasil Pengukuran Monitoring dan Evaluasi Kegiatan

\section{SIMPULAN}

Berdasarkan uraian kegiatan pengabdian masyarakat yang telah dilaksanakan, dapat ditetapkan kesimpulan sebagai berikut.

1. Mitra memahami pentingnya fungsi dan manfaat dari pengemasan yang baik serta peranan labeling produk sebagai identitas usaha, pengukuran pemahaman menggunakan form monitoring dan evaluasi kegiatan pengabdian masyarakat dengan nilai rata - rata untuk pelaksanaan kegiatan penyuluhan sebesar $80 \%$ dengan kompetensi pembicara sebesar 93\% dan pemahaman mitra terhadap materi yang disampaikan sebesar $75 \%$.

2. Mitra memiliki kemasan baru dalam model standing pouch bening dan label kemasan belakang produk dan depan produk menggunakan label nama "KOPI ODAH"

3. Secara keseluruhan kegiatan sudah berjalan sesuai dengan harapan dan berdasarkan hasil pengukuran evaluasi dan monitoring kegiatan secara keseluruhan diperoleh nilai sebesar $83 \%$ mitra menyatakan puas terhadap kegiatan pengabdian ini.

4. Saran atau masukan yang diberikan terkait dengan pelaksaan kegiatan dapat dilanjutkan di masa mendatang dengan mengadakan kegiatan promosi atau penjualan secara daring baik 
melalui media sosial atau bekerjasama dengan e-commerce atau pun memiliki website sendiri untuk memperluas pangsa pasar atau menemukan pasar baru .

\section{UCAPAN TERIMA KASIH}

Penulis mengucapkan terima kasih kepada Ibu Nyoman Resa khususnya dan keluarga besar Kopi Odah yang telah telah bersedia menjadi mitra dan mendukung penuh kegiatan ini, serta kepada Rektor ITB STIKOM Bali yang telah memberikan kesempatan dan pendanaan kegiatan pengabdian masyarakat ini.

\section{DAFTAR PUSTAKA}

K. Budiarta, "Sejarah Desa Bakas," 2020. [Online]. Available: https://bakas.desa.id/index.php/first/ $\underline{\operatorname{artikel} / 99}$

B. P. S. (. K. Klungkung, "Publikasi Katalog," 2802 2020. [Online]. Available: https://klungkungkab.bps.go.id/publi cation. [Diakses 1306 2020].

C. Cenadi, "Peranan Desain Kemasan Dalam Dunia Pemasaran," Nirmala , vol. 2, no. 1, pp. 93 - 103, 2019.

W. Iwan, Kemasan Yang Menjual, Jakarta: PT. Gramedia Pustaka Utama, 1999.

W. J. M. J. Lovelock Christopher, Stretegi Teknologi Dalam Pemasaran Jasa, Jakarta: PT. Erlangga , 2012. 